\title{
Political Trust and Public Satisfaction: A Logistic Regression Analysis Based on 1113 Samples
}

\author{
Zhouqiang Li \\ School of Public Management, Jinan University, Guangzhou, China \\ Email: lizhouqiang2015@163.com
}

How to cite this paper: Li, Z.Q. (2017) Political Trust and Public Satisfaction: A Logistic Regression Analysis Based on 1113 Samples. Open Journal of Business and Management, 5, 208-214.

http://dx.doi.org/10.4236/ojbm.2017.51019

Received: December 12, 2016

Accepted: January 21, 2017

Published: January 24, 2017

Copyright $\odot 2017$ by author and Scientific Research Publishing Inc. This work is licensed under the Creative Commons Attribution International License (CC BY 4.0).

http://creativecommons.org/licenses/by/4.0/

\begin{abstract}
As an indispensable part of government performance evaluation, the public plays an important role in the legitimacy of the Chinese government. Based on the 1113 samples of "Deliberative Democracy and Election Survey (2010, 2013 and 2014)", this paper studies the relationship between different levels of political trust and public satisfaction. Through descriptive statistics it was found that more than half of the public on the work of the government expressed satisfaction with the government level, and the degree of trust is gradually increasing. Logistic regression model found that political trust and public satisfaction have a significantly positive correlation, and this correlation strength in different levels of government is different. In addition, gender, political landscape and public satisfaction also have a significant correlation.
\end{abstract}

\section{Keywords}

Political Trust, Public Satisfaction, Logistic Model

\section{Introduction}

Government performance has always been the basis of the legitimacy of the Chinese government [1]. Public satisfaction is the most direct object of public policy, and also the most important consumer of public goods and public services. They have the greatest saying in the quality and service level of public policy. Therefore, public satisfaction has become an indispensable part of the government performance evaluation system. The public's subjective feelings can be directly fed back to the quality of the government's public service. On the other hand, it can be regarded as an important measure to supervise the government to improve the quality and efficiency of public service [2]. Historical experience shows that in the process of national major transition, the public's political trust is an important factor that affects the government's ability to implement the public policy. The higher the public satisfaction with the government, the more successful policy implementation is, even when the policy mistakes, the public will be- 
lieve the government, patiently waiting for the government to rectify [3]. Therefore, to explore the relationship between the political trust and public satisfaction, in theory the rational choice of Chinese people's political trust can be examined, and contribute to the transformation of the government in the process of public policy formulation and implementation to provide empirical evidence. This is an important significance link in the research of political trust.

Satisfaction survey is an important issue in business and marketing. It gradually extended to the government and the public policy evaluation after 1980s. From the Cradozo study of customer expectation and customer satisfaction [4], many theoretical models have been used to explain the influence factors of customer satisfaction, including micro factors and macro factors. On the micro level, the expectation is inconsistent [5], fair [6] and attributed [7] to explain customer satisfaction. On the macro level, the system analysis model is established by using the concept of customer satisfaction and value [8], quality [9] [10] and so on. But the empirical analysis of public satisfaction especially political trust and public satisfaction is rare. The research on the relationship between the two has theoretical and practical significance.

The rest of the paper is organized as follows. Section 2 describes the data source and gives descriptive analysis. In Section 3, we introduce the method we have used. Section 4 presents our empirical findings and Section 5 makes a conclusion.

\section{Data Sources and Description Analysis}

\subsection{Data Sources}

The data used in this paper are the "Deliberative Democracy and Election Democracy", which is presided by Ma Deyong who is associate professor at Zhou Enlai School Government, Nankai University. In order to understand the evolution of the development of Chinese democracy at the grassroots level, the data were analyzed by questionnaire and interview in the township China in Sichuan province and Zhejiang Province in 2010, 2013 and 2014, the final entry of 1987 questionnaires. In this study, the non probability sampling method was used to study the sample of the village and town in each region. Each place considering the level of local economic development, social security, and the relationship between the government and the people from the city (county) and other factors, select 2 - 3 townships, each township in 2 - 3 village population is relatively concentrated, and then to the village the villagers issued a questionnaire. According to the research needs of this paper, we have carried on the pretreatment to the data. Delete the sample "does not know", "do not want to say" and missing values, the final total of the sample is 1113 .

\subsection{Description Analysis}

The purpose of this study is to examine the relationship between political trust and public satisfaction at different levels of government. We assume that the higher the government's political trust, the higher the public satisfaction will be. Taking into account the limitations of the sample survey data, by asking the respondents, "Overall, you are satisfied with the current local township or town government work" to measure public satisfaction, respondents can choose between "satisfaction" and "dissatisfaction". 
The answer to this question reflects the respondent satisfaction on the work of the government, in the research hypothesis in the dependent variable. Public satisfaction with $\mathrm{Y}$ said that if the respondents chose "satisfaction", then $\mathrm{Y}=1$; If respondents choose "dissatisfaction", then $\mathrm{Y}=0$. Because the dependent variable is two variables, this study uses Logistic regression model to analyze. As shown in Table 1, the choice of "satisfaction", "dissatisfaction" is $57.4 \%, 42.6 \%$, more than half of the respondents to the township or town government's work is satisfactory.

Respondents responded to the level of trust in different levels of government, which is the measure of political trust of independent variables. Government level from high to low, divided into the central government, provincial governments, county governments and local governments. Respondents to different levels of government levels of trust can be from "very trust", "trust", "less trust" and "completely distrust" in the choice. The degree of trust is expressed by $X_{m}(m=1,2,3,4$ respectively indicated that the central government, the provincial government, the county government and the local government). If the respondents chose "very trust", then $X_{m}=1$; If respondents choose "trust", then $X_{m}=2$; If respondents choose "less trust", then $X_{m}=3$; If the respondents chose "completely distrust", then $X_{m}=4$. As shown in Table 2 the respondents to different levels of government trust: Overall, respondents were trusted by the government; for governments at different levels, the level of confidence in the government's trust in the government is decreasing with the level of government, which the respondents to the central government trust is higher than the trust of local governments. On the one hand, it shows that the central government has a legal basis in the minds of respondents. On the other hand, it also shows that the local government has not made more contact with the respondents than the central government's political trust.

Finally, this study also used the demographic variables, such as gender, race, age, political outlook and annual income of the family. The variables are controlled in the operation process after the code assignment is carried out. In the effective data analysis, respondents accounted for $57.1 \%$ of male, female accounted for $42.9 \%$, the average age

Table 1. Percentage of public satisfaction.

\begin{tabular}{ccc}
\hline Y & frequency & percentage \\
\hline 1 & 639 & 57.4 \\
0 & 474 & 42.6 \\
Total & 1113 & 100 \\
\hline
\end{tabular}

Table 2. Descriptive statistics of political trust at different levels.

\begin{tabular}{ccccc}
\hline$X_{m}$ & mean & standard deviation & minimum & maximum \\
\hline$X_{1}$ & 1.61 & 0.686 & 1 & 4 \\
$X_{2}$ & 1.98 & 0.690 & 1 & 4 \\
$X_{3}$ & 2.17 & 0.758 & 1 & 4 \\
$X_{4}$ & 2.36 & 0.828 & 1 & 4 \\
\hline
\end{tabular}


of respondents was 42 years old. Belong to the proportion of the Han nationality accounted for $99.2 \%$, minority accounted for $0.8 \%$. There are $15.6 \%$ members of the Communist Party of China, $1.2 \%$ belongs to the Democratic Party, $83.2 \%$ belong to the non Party (common people). Respondents, the family income (unit: yuan) accounted for $17.6 \%$ of the 10 thousand, 10 thousand - 10 million of $66.9 \%$, accounting for more than $15.5 \%$ of 100 thousand. Control variable assignment as shown in Table 3.

\section{Method}

The purpose of this study is to examine whether the respondents' trust in different levels of government as an independent variable and how they affect the public satisfaction. The dependent variable is "satisfaction" and "dissatisfaction", and the two is the two categories. So linear regression is not applicable (linear regression dependent variable is the range between positive infinity and negative infinity). The econometric models are used to interpret the data of discrete variables, including the probit model and the logistic model. Because the probit model needs to evaluate the overall multiple normal distribution, so its application is limited, and the logistic model of the sample does not need to obey the normal distribution scope, with more extensive than other models.

A dependent variable is $Y$, the value of 1 indicates that the public is satisfied with the work of the local government; value 0 indicates that the public is not satisfied with the work of the local government. There are $\mathrm{m}$ independent variables affecting $\mathrm{Y}: \mathrm{X}_{1}, \mathrm{X}_{2}$, $\mathrm{X}_{3}, \mathrm{X}_{4}(1 \leq \mathrm{m} \leq 4)$. The probability for a public $\mathrm{i}$ to work with the local government is $\mathrm{p}(\mathrm{y}=1 \mid \mathrm{X})=p_{i}$. The probability that the public are not satisfied with the work of the local government is $1-p_{i}$. Both of them are nonlinear functions of the independent variable vector $\mathrm{X}$ :

$$
p_{i}=\frac{1}{1+e^{-\left(\alpha+\sum_{i=1}^{m} \beta_{i} x_{i}\right)}}=\frac{e^{\alpha+\sum_{i=1}^{m} \beta_{i} x_{i}}}{1+e^{\alpha+\sum_{i=1}^{m} \beta_{i} x_{i}}}, 1-p_{i}=\frac{e^{\alpha+\sum_{i=1}^{m} \beta_{i} x_{i}}}{1+e^{\alpha+\sum_{i=1}^{m} \beta_{i} x_{i}}}=\frac{1}{1+e^{\alpha+\sum_{i=1}^{m} \beta_{i} x_{i}}}
$$

The probability of the public to satisfied and not satisfied with the attitude of the local government work ratio $p_{i} /\left(1-p_{i}\right)$ is called the event occurrence ratio, replacing

Table 3. Description and assignment of control variables.

\begin{tabular}{cl}
\hline control variables & \multicolumn{1}{c}{ assignment } \\
\hline gender & $1=$ male $2=$ female \\
race & $=$ Han $2=$ ethnic minorities \\
age & $=15-24,2=25-34,3=35-44,4=45-54,5=55-64$, \\
6 & $=65-74,7=75-84,8=85-94,9=95-104$ \\
1 & $=$ Chinese Communist Party, \\
2 & $=$ Democratic Party, $3=$ Non partisan (common people) \\
1 & $=1000$ the following, $2=1000-2000,3=2000-4000,4=4000-6000$, \\
political outlook & $=6$ thousand -10 thousand, $6=10$ thousand -20 thousand, \\
7 & $=20$ thousand -30 thousand, $8=30$ thousand -40 thousand, \\
9 & $=40$ thousand -60 thousand, $10=60$ thousand -100 thousand, \\
11 & $=100$ thousand -200 thousand, $12=200$ thousand -500 thousand, \\
13 & $=500$ thousand -1 million, $14=$ more than 1 million \\
annual income &
\end{tabular}


with Odds. Odds must be positive (because $0<p_{i}<1$ ), and there is no upper bound. Logarithmic transformation of Odds, the linear expression of the logistic regression model:

$$
\ln \left(\frac{p_{i}}{1-p_{i}}\right)=\alpha+\sum_{i=1}^{m} \beta_{i} x_{i}
$$

In Formula (1) and Formula (2), $\alpha$ is constant, $m$ as the number of independent variables; $\beta_{i}$ is the coefficient of the independent variable, which reflects the direction and extent of the independent variables affecting public satisfaction.

\section{Empirical Result}

The primary objective of this study was to examine whether political trust can affect public satisfaction and how. Pearson correlation analysis of the control variables and the independent variables, the regression coefficient significance level $\mathrm{P}$ value is greater than 0.05 , which shows that the independent variable does not exist. Model 1 is the control of gender, race, age, political outlook, family income with demographic characteristics of the variables, and its regression with the dependent variables. Model 2, 3, 4, 5 are based on the model 1 , respectively, the central government, provincial government, county government and the local government's trust as the independent variable, the public satisfaction as the dependent variable regression. The results of the regression model are shown in Table 4.

In combination with Table 4, only the gender and political appearance were significantly correlated with the dependent variables in model 1. Male respondents satisfaction than female respondents, the more non partisan (common people), satisfaction will be higher, the other control variables do not have a statistically significant correlation. Model 2, 3, 4, 5 based on the model 1. Under the influence of the control varia-

Table 4. Logistic regression model of political trust and public satisfaction.

\begin{tabular}{|c|c|c|c|c|c|c|c|c|c|c|}
\hline & \multicolumn{2}{|c|}{ model 1} & \multicolumn{2}{|l|}{ model 2} & \multicolumn{2}{|l|}{ model 3} & \multicolumn{2}{|l|}{ model 4} & \multicolumn{2}{|l|}{ model 5} \\
\hline & B (S.E) & $\operatorname{Exp}(B)$ & B (S.E) & $\operatorname{Exp}(B)$ & B (S.E) & $\operatorname{Exp}(B)$ & B (S.E) & $\operatorname{Exp}(B)$ & B (S.E) & $\operatorname{Exp}(B)$ \\
\hline \multicolumn{11}{|c|}{ control variable } \\
\hline gender & $-0.295^{\star}(0.127)$ & 0.745 & $-0.425^{\star *}(0.132)$ & 0.653 & $-0.459^{\star *}(0.138)$ & 0.632 & $-0.341^{\star}(0.141)$ & 0.711 & $-0.249^{*}(0.150)$ & 0.780 \\
\hline race & $0.639(0.681)$ & 1.894 & $0.756(0.682)$ & 2.130 & $0.735(0.748)$ & 2.085 & $0.529(0.750)$ & 1.697 & $0.542(0.797)$ & 1.720 \\
\hline age & $-0.001(0.004)$ & 0.999 & $0.006(0.005)$ & 1.006 & $0.009(0.005)$ & 1.009 & $0.008(0.005)$ & 1.008 & $0.002(0.005)$ & 1.002 \\
\hline political outlook & $0.303^{* *}(0.088)$ & 1.354 & $0.293^{* *}(0.090)$ & 1.341 & $0.262^{\star \star}(0.093)$ & 1.300 & $0.226^{*}(0.096)$ & 1.253 & $0.127^{\star}(0.104)$ & 1.135 \\
\hline family income & $0.007(0.023)$ & 1.007 & $-0.003(0.024)$ & 0.997 & $-0.020(0.025)$ & 0.981 & $-0.018(0.026)$ & 0.983 & $-0.017(0.028)$ & 0.984 \\
\hline \multicolumn{11}{|c|}{ independent variable } \\
\hline $\mathrm{X}_{1}$ & & & $0.575^{\star * *}(0.099)$ & 1.778 & & & & & & \\
\hline $\mathrm{X}_{2}$ & & & & & $0.253^{\star * *}(0.113)$ & 0.500 & & & & \\
\hline $\mathrm{X}_{3}$ & & & & & & & $0.394^{\star * *}(0.032)$ & 0.032 & & \\
\hline $\mathrm{X}_{4}$ & & & & & & & & & $0.727^{\star * *}(0.114)$ & 0.623 \\
\hline constant & $-1.348(0.822)$ & 0.260 & $-2.414(0.849)$ & 0.089 & $-3.840(0.927)$ & 0.021 & $-4.231(0.935)$ & 0.015 & $-4.931(0.996)$ & 0.007 \\
\hline
\end{tabular}

Standard errors in parentheses: ${ }^{\star} P \leq 0.05,{ }^{* *} P \leq 0.001,{ }^{* *} P \leq 0.0001$. 
bles, the regression analysis of different levels of political trust and public satisfaction. The results of the four models show that there is a significant positive correlation between different levels of political trust and public satisfaction: respondents believe that the government, the government's work will be more positive attitude. The difference between the four models is that the correlation strength of each model is different: $B_{5}>$ $B_{2}>B_{4}>B_{3}$. The more respondents believe that the government will be satisfied with government, this correlation strength reflected in the strongest local government, the central government, the county government again, the weakest level of the provincial government.

\section{Conclusions}

The empirical analysis of the influencing factors of satisfaction degree is different with the past. This study explores the relationship between political trust and public satisfaction from the perspective of public trust in different levels of government. Through the survey data of 1113 samples, we found that the political trust in different levels has a significantly positive correlation with public satisfaction. The more respondents to the government trust, the more the government's work will hold a positive attitude. At the same time, the different levels of political trust in public satisfaction of the correlation strength showed that different levels of government correlation strength are not the same. The intensity of this correlation is reflected in the strongest local government, the central government, the county government again, and the weakest level of the provincial government. This may be affected by the public's familiarity with the government.

Therefore, the government's legal status is more stable, and the public's performance evaluation of the government becomes essential. Political trust has a significantly positive correlation with public satisfaction, which can indirectly improve public satisfaction by improving the public's political trust. First, the links between the government and the public at all levels should be strengthened, and the level of social services in the community and streets to help enhance the public's political trust should be enhanced. Secondly, through the sound and perfect local laws and regulations, a good social environment should be created, so that the public and the government can conduct social exchanges and cooperation under the rule of law. Finally, in the community and the streets by the government, the lead in holding a number of political, cultural and recreational activities should be taken, to promote exchanges and communication between the government and the public.

\section{References}

[1] Zhao, D. (2009) The Mandate of Heaven and Performance Legitimation in Ancient and Contemporary China. American Behavioral Scientist, 53, 416-433. https://doi.org/10.1177/0002764209338800

[2] Cai, L.H. (2012) Government Performance Measurement. Renmin University of China press, Beijing, 59-60.

[3] Yang, Q. and Tang, W. (2010) Exploring the Sources of Institutional Trust in China: Culture, Mobilization, or Performance? Asian Politics \& Policy, 2, 415-436. https://doi.org/10.1111/j.1943-0787.2010.01201.x

[4] Cardozo, R.N. (1965) An Experimental Study of Customer Effort, Expectation, and Satis- 
faction. Journal of Marketing Research, 2, 244-249. https://doi.org/10.2307/3150182

[5] Zhang, B. and Li, J.B. (2014) An Empirical Analysis on the Influencing Factors of College Teaching Satisfaction: Based on the Perspective of Students' Expectation and Students' Perceived Quality. Fudan Education Forum, No. 4, 59-65.

[6] Sun, J.S. and Cheng, F.F. (2016) Starting Point Fairness, Procedural Fairness, Outcome Fairness and Distributive Fairness Satisfaction. Economic Theory and Economic Management, 36, 25-42.

[7] Chen, L. (2016) An Empirical Study on the Performance Satisfaction of the Rule of Law Government: Based on the Sampling Survey of Guangxi in 2014. Academic Forum, No. 5, 115-121.

[8] Feng, F. and Zhong, Y. (2016) An Empirical Study of China's Public Satisfaction with Government Services: Based on Surveys in 10 Cities. The Journal of Shanghai Administration Institute, 17, 58-72.

[9] Zou, K., Zuo, S., Chen, Y. and Jiang, Z.Y. (2016) Government Information Services Public Satisfaction Evaluation Study Based on Network Public Opinion. Information Science, 34, 45-49.

[10] Jiang, X.J. and Ma, F.S. (2015) An Empirical Study of China's Tibetan Local Government Basic Public Services and Public Satisfaction: Analysis of Diqing Tibetan Autonomous Prefecture in Yunnan Province Based on the Questionnaire Survey of 305 Households. The Journal of Yunnan Administration College, No. 6, 63-67.

\section{Submit or recommend next manuscript to SCIRP and we will provide best service} for you:

Accepting pre-submission inquiries through Email, Facebook, LinkedIn, Twitter, etc. A wide selection of journals (inclusive of 9 subjects, more than 200 journals)

Providing 24-hour high-quality service

User-friendly online submission system

Fair and swift peer-review system

Efficient typesetting and proofreading procedure

Display of the result of downloads and visits, as well as the number of cited articles

Maximum dissemination of your research work

Submit your manuscript at: http://papersubmission.scirp.org/

Or contact ojbm@scirp.org 